\title{
The Preventive Approach of Biocompounactives (1): A Review in Recent Advances in Common Vegetables and Legumes
}

\author{
Abdelkarim Guaâdaoui ${ }^{1, ~ *}$, Fatma Bouhtit ${ }^{2}$, Abdellah Hamal ${ }^{1}$ \\ ${ }^{1}$ Department of Biology, Laboratory of Genetics \& Biotechnology (LGB), Faculty of Science - Oujda (FSO), University Mohammed Premier \\ (UMP) Oujda, Morocco \\ ${ }^{2}$ Department biological analysis, Laboratory for Analysis and Quality Control (LACQ), University Mohammed Premier (UMP) Oujda \\ Morocco
}

Email address:

abdelkarim119@gmail.com (A. Guaâdaoui)

\section{To cite this article:}

Abdelkarim Guaâdaoui, Fatma Bouhtit, Abdellah Hamal. The Preventive Approach of Biocompounactives (1): A Review in Recent Advances in Common Vegetables and Legumes. International Journal of Nutrition and Food Sciences. Vol. 4, No. 1, 2015, pp. 89-102.

doi: $10.11648 /$ j.ijnfs.20150401.23

\begin{abstract}
All scientific studies confirm that a varied and balanced diet is factor of protection against cancer, cardiovascular disease (CVD), osteoporosis, diabetes, obesity and high cholesterol. The philosophy that food can be health promoting beyond its nutritional value is gaining acceptance within the public arena and among the scientific community as mounting research links diet/food components to disease prevention and treatment. Biocompounactives contain chemicals that are found in small quantities in plants and certain foods (such as fruits, vegetables, nuts, oils and whole grains), they have actions in the body that can promote good health. In this work, we focus on studies that have been conducted on biocompounactives of common vegetables and legumes, and opportunities that present bioactivity of these phytochemicals to prevent many chronic diseases. As well, emphasis is placed on some challenges that face the good investissment of biocompounactives.
\end{abstract}

Keywords: Biocompounactives, Bioactive Compound, Phytochemicals, Functional Foods, Healthy Diet, Nutraceuticals

\section{Introduction}

Biocompounactives are compounds which have the capability and the ability to interact with one or more component(s) of the living tissue by presenting a wide range of probable effects. These compounds are experiencing a growing interest in wide range of applications: geo-medicine, plant science, modern pharmacology, agrochemicals, cosmetics, food industry, nano-bio-science... etc. This is a very promising area in full development, which has resulted in research works more and more numerous, designed to diversify the resources of bioactive compounds and improve their salvage pathways or synthesis $[1,2]$.

The philosophy that food can be health promoting beyond its nutritional value is gaining acceptance within the public arena and among the scientific community as mounting research links diet/food components to disease prevention and treatment $[3,4]$. Noting that prevention is a more effective strategy than is treatment of chronic diseases [5].

Interest in food composition has expanded beyond the nutrients to include bioactive compounds consumed in the traditional foods, which may help to prevent many chronic diseases that can coexist with malnutrition and undernutrition [6].

Recent trends in the functional food market suggest that products with multiple health benefits become more and more popular [7] and dietary bioactive compounds have become another quality indication [8].

\section{Food Biocompounactives Opportunities}

The importance attached to benefits of food on health has never been so high before [3]. Indeed, over the past two decades, there has been a growing interest in the potential benefits of natural compounds on human health [9], and if we except the genetic, ecological, physiological and botanical studies on food; research on the bioactive potential has experienced a veritable boom during the first decade of the 
twenty-first century, and took an accelerated rates over the beginning of the second decade, in a way that the research carried out during the past five years (2010-2014) on the majority of foods are equal or superior to the work done during all the previous decade (2000-2009).

Biocompounactives are members of a large class of organic molecules that are widely distributed in the plant kingdom and, as such, are an integral part of the daily diet of humans [10].

Until 2013, it was estimated that more than 8000 phytochemicals have been identified in foods [11]. All these bioactive food components are mostly found in whole grains, fruits and vegetables [12, 13], but a large percentage still remain unknown and need to be identified before we can fully understand the health benefits of phytochemicals in whole foods [12].

The phytochemicals may be classified into carotenoids, phenolic compounds, alkaloids, nitrogen compounds and organosulfur compounds. But the most studied of these biocompounactives are phenolics and carotenoids [14].

Recent investigations show that food biomolecules that contribute to human health can be found particularly in glycosylated, esterified, thiolated or hydroxy forms. These bioactive compounds display their health benefits in metabolic activity associated with several diseases [13].

Liu RH (2003) proposes that cumulative and synergistic effects of phytochemicals in fruits and vegetables are responsible for their powerful antioxidant and anticancer activities, and the benefit of a diet rich in fruits and vegetables is attributed to the complex mixture of phytochemicals found in whole foods [5].

So the important role that biocompounactives can have in health is related to the intake of these compounds, which, in turn, strongly linked to the high consumption of fruits, vegetables and unrefined grains [15]. Indeed, several studies have shown that a high intake of fruits and vegetables reduces the risk of cardiovascular disease, certain cancers, and other chronic diseases [14, 16-19].

The concept of a healthy diet is considered an aspect of good and healthy practices. The observations in social behavior and archaeological discoveries lead researchers to notice that the longevity and healthy life, away from the high incidence of myocardial infarction and cancer, are caused by good habits of feeding [20].

Thus, several studies have demonstrated a significant reduction in the risk of chronic diseases, and beneficial health effects of bioactive compounds of certain eating habits and diets, such as the traditional Japanese diet that contains a high content of soy products and vegetables [21-23], the Mediterranean diet [15, 24-26], which contains a high content of olive oil, fruits and vegetables, and wholegrain bread; and the regime of "prudence" diet [27, 28] which is characterized by a high consumption of fruits and vegetables, fish and poultry, whole grains (barley, oats, rice ...) and legumes.

Early in 2013, for example, a scientific study conducted on 7500 people who were observed over a period of five years has revealed that those who have a Mediterranean diet reduced the risk of heart disease by $30 \%$ compared to people who follow a diet low in fat alone [29]. Several studies have reached similar conclusions [30-36], and mortality statistics from the World Health Organization (WHO) have provided evidence that diet in Mediterranean countries had health implications in respective populations and, in particular, their coronary health [37].

Table 1 constitutes a concise review of common vegetables and legumes, their bioactive constituents and bioactivities studied that present enormous opportunities for human health.

Table 1. Bioactivity of dietary biocompounactives (vegetables and legumes case).

\begin{tabular}{|c|c|c|c|}
\hline Vegetables \& Legumes & Bioactivities studied & Biocompounactives & References \\
\hline $\begin{array}{l}\text { Artichoke } \\
\text { Cynara cardunculus } \\
\text { (Asteraceae) }\end{array}$ & $\begin{array}{l}\text { Reduce the risk of colon cancer / Prevent constipation } \\
\text { Control of type } 2 \text { diabetes } \\
\text { Treat high cholesterol } \\
\text { Effectiveness of the intestinal flora }\end{array}$ & $\begin{array}{l}\text { Phenolic compounds: Caffeoylquinic } \\
\text { acid } \\
\text { Soluble and insoluble fiber (inulin) }\end{array}$ & [38-48] \\
\hline $\begin{array}{l}\text { Bean } \\
\text { Phaseolus vulgaris } \\
\text { (Fabaceae) }\end{array}$ & $\begin{array}{l}\text { Lower risk oesophageal and stomach cancer } \\
\text { Modulate cardiovascular risk factors and obesity } \\
\text { Decreased bone degradation } \\
\text { Anti-tumor, antioxidant \& phyto-estrogenic activities }\end{array}$ & $\begin{array}{l}\text { Flavonoids (quercetin) } \\
\text { Saponins } \\
\text { Propionic \& Oleanolic acids } \\
\text { Fiber }\end{array}$ & {$[49-60]$} \\
\hline $\begin{array}{l}\text { Beet } \\
\text { Beta vulgaris } \\
\text { (Chenopodiaceae) }\end{array}$ & $\begin{array}{l}\text { Anti-tumor / Anti-inflammatory } \\
\text { Antidiabetic \& Liver protection } \\
\text { Prevent dementia and cognitive decline }\end{array}$ & $\begin{array}{l}\text { Betalain } \\
\text { Flavonoids } \\
\text { Lutein \& Zeaxanthin } \\
\text { Fiber }\end{array}$ & {$[2,61-69]$} \\
\hline $\begin{array}{l}\text { Cabbage } \\
\text { Brassica oleracea } \\
\text { Cauliflower } \\
\text { Brassica oleracea var. } \\
\text { botrytis. } \\
\text { (Brassicaceae) }\end{array}$ & $\begin{array}{l}\text { Decrease of overall cancer risk } \\
\text { Self-destruction of cancer cells } \\
\text { Lower risk of lung cancer and pancreatic cancer } \\
\text { Slow cognitive decline (in women) } \\
\text { Control diabetes } \\
\text { Immunomodulatory }\end{array}$ & $\begin{array}{l}\text { Flavonoids (cyaniding) } \\
\text { Carotenoids } \\
\text { Tocopherols } \\
\text { Glucosinolate (Sinigrin \& } \\
\text { Glucobrassicin) } \\
\text { Allyl isothiocyanate (AITC) } \\
\text { Fiber }\end{array}$ & {$[70-85]$} \\
\hline $\begin{array}{l}\text { Carrot } \\
\text { Daucus carota } \\
\text { (Apiaceae) }\end{array}$ & $\begin{array}{l}\text { Prevent certain cancers (lung, breast, blood) } \\
\text { Prevent atherosclerotic process (CVD) } \\
\text { Prevent some age-related diseases such as cataracts } \\
\text { Antidiabetic potential / Lower cholesterol and triglycerides }\end{array}$ & $\begin{array}{l}\text { Carotenoids: beta-carotene, lutein \& } \\
\text { zeaxanthin } \\
\text { Crotonic acid } \\
\text { Polyacetylene } \\
\text { Soluble fiber }\end{array}$ & [86-93] \\
\hline Chickpea & Beneficial effects on the bacterial colonic flora & Flavonoids & [94-105] \\
\hline
\end{tabular}




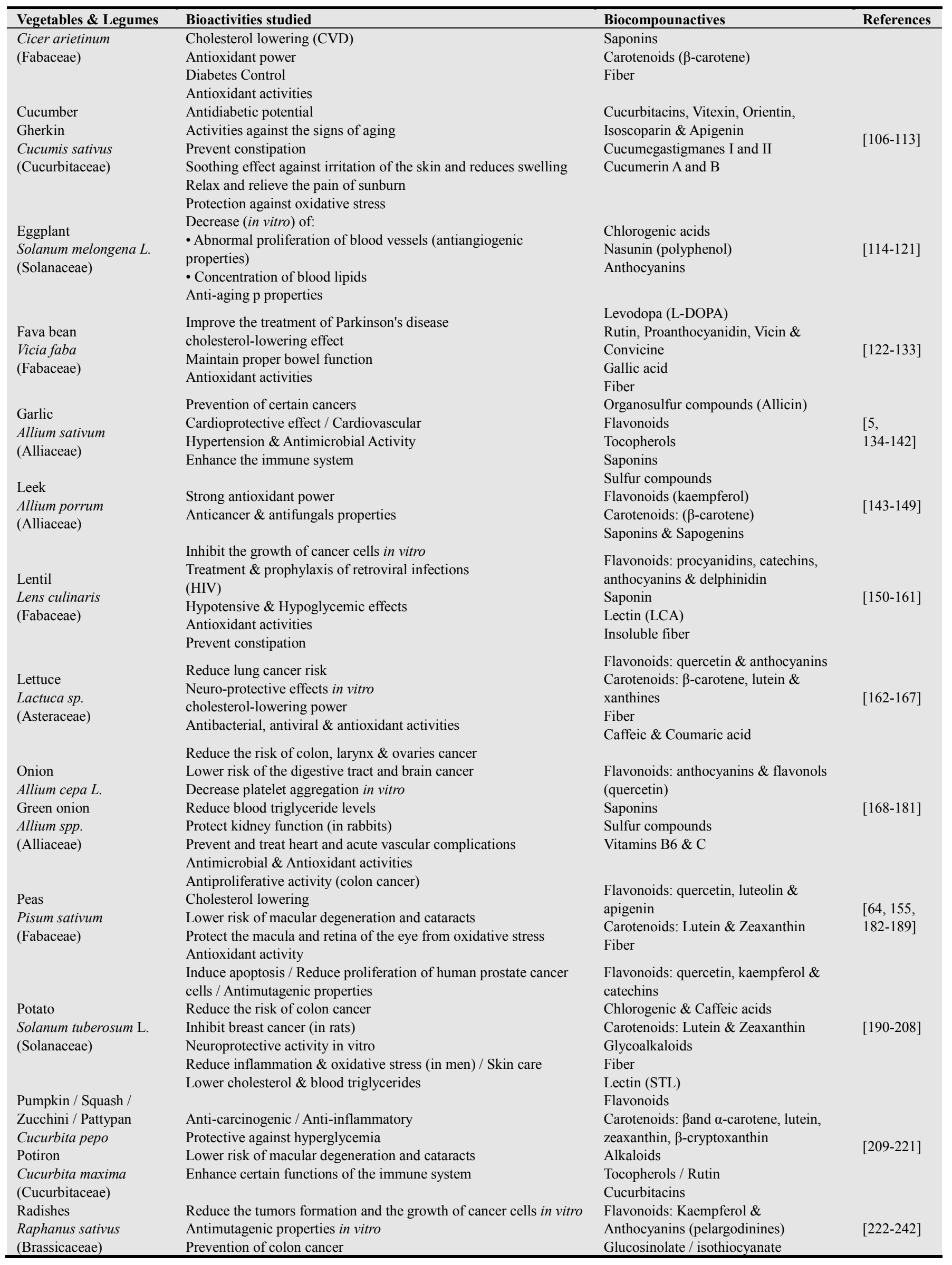




\begin{tabular}{lll}
\hline Vegetables \& Legumes & Bioactivities studied & Biocompounactives \\
\hline & $\begin{array}{l}\text { Slow cognitive decline (in older women) } \\
\text { Accentuate intestinal motility in animals (stimulate the digestive } \\
\text { system and promote intestinal elimination) } \\
\text { Lower cholesterol \& triglycerides }\end{array}$ & Methyl-isogermabullone \\
& & \\
& Limit the development of cancer cells and some metastases & $\begin{array}{l}\text { Glucosinolates / Phenylethyl } \\
\text { isothiocyanate (PEITC) }\end{array}$ \\
$\begin{array}{l}\text { Turnip } \\
\text { Brassica rapa } \\
\text { (Brassicaceae) }\end{array}$ & $\begin{array}{l}\text { Antioxidant protection in tissues } \\
\text { Lower risk of macular degeneration and cataracts }\end{array}$ & \begin{tabular}{l} 
Carotenoids: Lutein \& Zeaxanthin \\
Hydroxycinnamic acids / Vitamin C \\
\hline
\end{tabular} \\
\hline
\end{tabular}

\section{Challenges of the Preventive Approach of Biocompounactives}

\subsection{How to Provide Science to the Public}

The diet reflects the preferences and eating habits, and diversity of human experiences, which have evolved in many models over time [255], knowing that indigenous peoples have never separate food from medicine, on how our modern world is now [256]. Unfortunately, social changes seem to have always contributed to the radical reversal dietary habits $[257,258]$, and the real challenge on this side is how to adopt such a healthy diet in a world more and more westernized [259], and save the transmission of knowledge in terms of traditional gestures, celebrations, rituals and techniques, which continue to lose today [256, 257].

On the other side, and despite all the efforts of many government [260-264] and international institutions [265], the available nutrition information can seem quite complex, not well understood by the majority of consumers, and of limited use when preparing family menus without a good knowledge. It is therefore necessary to provide advice in a way that consumers can understand [262].

In this framework, Herber D. (2002) proposes a method to translate the science of dietary phytochemicals, in dietary recommendations for the public, with the selection of foods based on colors that encode the content of phytochemicals $[266,267]$. The author has categorized foods according to their colors into seven groups (Table 2) which consumers should ingest a portion of each of the seven groups every day, and requested the concerned institutions to introduce 5-9 portions among the recommendations, where the total amount will be between 400 and $600 \mathrm{~g} /$ day of fruits and vegetables. This quantity is associated with a reduced incidence of many common cancers. According to international studies, for some cancers of the aerodigestive tract, the risk is reduced by $50 \%$ [268, 269].

The grouping of plant foods by color provides simplification to encourage increased intake of fruits and vegetables, but it is also important as a method to help consumers to make wise food choices and promote health. For example, red foods contain lycopene, pigment of tomato, which is localized in the prostate gland and may be involved in maintaining the health of the prostate, which was also linked to a decrease in the risk of cardiovascular disease. Green foods, including broccoli, Brussels sprouts and cauliflower, contain glucosinolates that have been associated with a decreased risk of cancer. Garlic and other white-green foods in the onion family contain allyl sulfides that can inhibit the growth of cancer cells. Other bioactive substances in green tea and soy also have health benefits... etc. [267, 268].

Table 2. The color-code of food groups [268] (modified) [301]*.

\begin{tabular}{lll}
\hline Color & Phytochemicals & Examples \\
\hline Red & Lycopene & Tomato \\
Red / Purple & Anthocyanins \& Polyphenols & Grapes, berries \\
Orange & $\alpha$-and $\beta$-carotene & Carrot, pumpkin \\
Orange/Yellow & $\beta$-cryptoxanthin \& Flavonoids & Orange, melon \\
Yellow/Green & Lutein \& Zeaxanthin & Avocado, spinach \\
Green & Glucosinolates \& Indoles & Broccoli, cabbage \\
White/Green & Allyl sulfides & Garlic, onions \\
White* & Carotenoids \& Polyphenols & Potatoes, turnips \\
\hline
\end{tabular}

In 2013, Barnes S. et al. have criticized the method based on color, asking if we can 'see' what is good for us in nutrition? It is true that phytochemicals are the (different) food colors. But color is not necessarily an indication of what or how many phytochemicals, beneficial or toxic, are present in what we eat. The color can be an indicator of some phytochemicals, but not others. Although, the food colors can mislead the consumer about the actual content of nutrients and phytochemicals, as many of these compounds are colorless in one side or, on the other side, human eyes cannot directly judge the content of these compounds, because human vision is limited to a small window of the electromagnetic spectrum (390-765nm). Besides, several phytochemicals can be transformed or lost during the process undergone by food, such as cooking [270]. Thus, the authors highlight that dietary advice based on color is a wrong approach for overall content of bioactive compounds.

This debate leads us to put forward the possibility of the integration of biocompounactives directly into the dietary recommendations. But what is needed to develop a framework that can be used to make health recommendations for bioactive food components? The answer to this question has built the axis of discussions in a symposium held in April 2013 by the American Society for Nutrition (ASN, Boston).

Indeed, although a framework exists to establish recommendations for essential nutrients; such a framework does not exist for non-essential bioactive constituents in food. Despite a myriad of factors that make the measure of their contributions and the study of their effects difficult, a new framework to determine the recommended intakes for bioactive compounds is justified, since without dietary recommendations for biocompounactives, and from a public 
health point of view, there will be a perpetuation of the status quo of current diets containing lower food intake, and consequently of bioactive compounds that can support optimal health. While the transmission of accurate and reliable information about the health benefits of a large number of bioactive food components would improve public understanding of the importance of the safe use of these compounds for the promotion of health [271].

The development of an alternative path for formulating dietary recommendations for bioactive components encounter, in its turn, several challenges and obstacles. This approach will require, inter alia, strong scientific evidence, but also specialized resources and funds. And if the scientific community is trying to generate a valid and reliable literature, the necessary funding is not yet considered a priority, as bioactive substances are non-essential! Adding Gaine P.C. et al. (2013) in the summary of the symposium [271]. This means that dietary biocompounactives are not yet ready for integration with recommended intakes.

\subsection{Processed Foods}

In addition, the recommendations provide a wide range of forms of foods, including fresh, frozen, canned and dried food and juices [261, 272]. While many phytochemicals may be transformed or lost during food processing[270]. In general, treatment of fresh foods leads to changes in the composition of bioactive food components. These changes can be beneficial or detrimental to the total content of health-promoting phytochemicals compounds [273].

Methods of food processing may affect the content, activity and bioavailability of bioactive compounds in foods [274]. However, several phytochemicals are destroyed or reduced during processing $[275,276]$. For example, the phenolic compounds are generally considered to be relatively stable in storage at a cool temperature, but can be lost or degraded at high temperature [277, 278].

In this context, studies give results that cannot be generalized due to the intervention of several factors simultaneously. In tomatoes (fruits used as vegetables in cooking), for example, the pasteurization at high temperature $\left(98^{\circ} \mathrm{C}\right)$, even for a short time (40 seconds), reduces the content of total phenolic compounds [279]. However, another study reported that phenolics of tomato increased by $23-34 \%$ after bleaching at $100^{\circ} \mathrm{C}$ for 30 minutes [280]. While this increase in phenolic compounds is not always beneficial, it is true that it can be associated with an increase of antioxidant potential, but the oxidation of phenolic compounds may cause undesirable browning during storage of food; as it can be associated with an accumulation of some phenolic compounds such as isocoumarins which may cause a bitter taste [281-283].

Heat treatment is currently the most common method used for domestic and industrial food processing. It is the most widely used method to preserve and extend the useful life of the food [284]. Knowing that the nutritional value and phytochemical content of plant tissue is usually reduced during senescence and normal aging after harvest [285]. However, the thermal techniques have negative effects on biocompounactives in foods. To meet this challenge and ensure food security, while preserving the bioactive compounds, there needs to combined approaches and targeted studies on the stability of biocompounactives. While research shows that non-thermal technologies have the potential to improve the retention of bioactive compounds without compromising food security [286].

Besides the influence of treatment (or transformations) post-harvest, the content of phytochemicals in foods can be influenced by variety, environment and conditions of growth, maturity stages and harvesting factors [287-290], but little information is available on the influence of cultivation factors or genotype [291], while the impact of harvesting techniques and storage phytochemicals began to be explored in relatively recently [277]. In general, most studies on the application of food phytochemicals are limited to the examination of their bioactive efficiency rather than their stability during storage, for example [292].

\subsection{Allergic Reactions}

Finally, allergic reactions of food-borne are responsible for a variety of symptoms and disorders involving the skin and the gastrointestinal and respiratory tracts [293, 294]. The dose or the amount of food needed to trigger a clinically apparent reaction generally varies between individuals and even in the same individual over time. It also depends on metabolic differences, the concomitant use of drugs, the freshness of food and their preparation [295].

Potatoes, for example, like all plants of the genus Solanum, contain toxic glycoalkaloids. These are mainly $\alpha$-chaconine and $\alpha$-solanine, which represent $95 \%$ of total glycoalkaloids in modern cultivars [296]. When the potatoes are stored at high temperature or at light, the concentration of these alkaloids increases (green tint or spots), and cooking does not destroy these alkaloids [297]. After consumption, several symptoms could be triggered (tingling sensation in the mouth, bronchospasm, gastrointestinal discomfort ... etc.), and a large quantity consumption can lead to serious poisoning that may affect the central nervous system [297, 298].

\section{Conclusion}

Biocompounactives contain chemicals that are found in small quantities in plants and certain foods (such as fruits, vegetables, nuts, oils and whole grains), they have actions in the body that can promote good health [299].

All scientific studies confirm that a varied and balanced diet, with minimal physical activity, is factor of protection against cancer, cardiovascular disease, osteoporosis, diabetes, obesity and high cholesterol. True that these diseases do not depend exclusively on food, they are also influenced by genetic factors, but if we cannot choose our ancestors, we can choose our food and organize our lifestyle [300]!

In future studies, we continue on preventive approach of biocompounactives that contain fruits (part 2), cereals and some foods of animal origin (part 3), with discussion of other opportunities and challenges facing this approach. 


\section{Acknowledgements}

Abdelkarim G. thanks Professor Noureddine BOUKHATEM for directions and observations he provided during the preparation of this research.

\section{References}

[1] Abdelkarim $\mathrm{G}$ et al.; What is a bioactive compound? A combined definition for a preliminary consensus. International Journal of Nutrition and Food Sciences, 2014, 3(3): 174-179.

[2] Abdelkarim G et al.; Betalains, Polyacetylenes and Tocols as Biocompounactives: A Concise Review for Enriching the Bioactivity Concept. International Journal of Nutrition and Food Sciences, 2014, 3(4): 230-237.

[3] Bonaccio $\mathrm{M}$ et al.; The Mediterranean diet: The reasons for a success. Thrombosis Research, 2012, 129: 401-404.

[4] Abby B and Cynthia AT; Position of the American Dietetic Association: phytochemicals and functional foods. Journal of the American Dietetic Association, 1995, 95(4): 493-496.

[5] Liu RH; Health benefits of fruits and vegetables are from additive and synergistic combination of phytochemicals. The American Journal of Clinical Nutrition, 2003, 78(3S): $517 \mathrm{~S}-520 \mathrm{~S}$

[6] Biesalski HK et al. ; Bioactive compounds: Definition and assessment of activity. Nutrition, 2009, 25(11-12): 1202-1205.

[7] Day L et al.; Incorporation of functional ingredients into foods. Trends in Food Science and Technology, 2009, 20(9): 388-395.

[8] Park YS et al. ; Analytical determination of bioactive compounds as an indication of fruit quality. Journal of AOAC International, 2012, 95(6): 1725-1732.

[9] Teratanavat R and Hooker NH ; Consumer Valuations and Preference Heterogeneity for a Novel Functional Food. Journal of Food Science, 2006, 71(7): S533-S541.

[10] Pandey KB and Rizvi SI: Plant polyphenols as dietary antioxidants in human health and disease. Oxidative Medicine and Cellular Longevity, 2009, 2(5): 270-278.

[11] Liu RH; Potential Synergy of Phytochemicals in Cancer Prevention: Mechanism of Action. Journal of Nutrition, 2004, 134(12S): 3479S-3485S.

[12] Sreeramulu D et al.; Natural Antioxidant Activity of Commonly Consumed Plant Foods in India: Effect of Domestic Processing. Oxidative Medicine and Cellular Longevity, 2013 (2013): 1-12.

[13] Klotzbach-Shimomura $\mathrm{K}$; Herbs and health: safety and effectiveness. Journal of Nutrition Education, 2001, 33: 354-355.

[14] Willett WC; Balancing life-style and genomics research for disease prevention. Science, 2002, 296: 695-698.

[15] Collier R; Japanese longevity. Canadian Medical Association Journal, 2010, 182(12): E579.

[16] Kris-Etherton PM et al.; Recent discoveries in inclusive food-based approaches and dietary patterns for reduction in risk for cardiovascular disease. Current Opinion in Lipidology, 2002, 13(4): 397-407.
[17] Bazzano LA et al.; Dietary intake of fruits and vegetables and risk of cardiovascular disease. Current Atherosclerosis Reports, 2003, 5(6): 492-9.

[18] Lampe JW; Health effects of vegetables and fruit: assessing mechanisms of action in human experimental studies. The American Journal of Clinical Nutrition, 1999, 3(70): 475S-90S.

[19] Harding AH et al.; Plasma vitamin C level, fruit and vegetable consumption, and the risk of new-onset type 2 diabetes mellitus: the European prospective investigation of cancer--Norfolk prospective study. Archives of Internal Medicine, 2008,168: $1493-9$

[20] Schauss AG ; Emerging Knowledge of the Bioactivity of Foods in the Diets of Indigenous North Americans (Chapter 5). Bioactive Foods in Promoting Health: Fruits and Vegetables, Elsevier Inc., 2010: 71-84.

[21] Said MM; The Wonders Of Mediterranean Diet, The Internet Journal of Nutrition and Wellness (ISPUB), 2004, 1(1): 1-6.

[22] Kato $\mathrm{H}$ et al.; Epidemiologic studies of coronary heart disease and stroke in Japanese men living in Japan, Hawaii and California. American Journal of Epidemiology, 1973, 97(6): $372-85$.

[23] Sadamori S et al.; The relationships between oral status, physical and mental health, nutritional status and diet type in elderly Japanese women with dementia. Gerodontology, 2008, 25(4): 205-209.

[24] Fulgencio SC and Isabel G; Definition of the Mediterranean diet based on bioactive compounds. Critical Reviews in Food Science and Nutrition, 2009, 49(2): 145-52.

[25] de Lorgeril M. et al.; Mediterranean diet, traditional risk factors, and the rate of cardiovascular complications after myocardial infarction: final report of the Lyon Diet Heart Study, 1999, Circulation 99(6): 779-85.

[26] Claudio G; Bioactive components in Mediterranean diets: From historical and ethnobotanical considerations to nutraceutical applications. Nutrafoods, 2012, 11(1): 11-17.

[27] Maria K et al.; The role of Mediterranean diet in health and disease: an updated mini review. Nutrition \& Food Science, 2011, 41(1): 63-72.

[28] Terry P et al.; Prospective study of major dietary patterns and colorectal cancer risk in women. American Journal of Epidemiology, 2001, 154(12): 1143-49.

[29] Altomare R et al.; The Mediterranean Diet: A History of Health Iranian Journal of Public Health, 2013, 42(5): 449-457.

[30] Sarah H ;The Mediterranean Diet: Melting the Fat Away With the Wonder Diet. The Mediterranean Diet Meltdown, 2013: $1-36$.

[31] Robertson RM and Smaha L; Can a Mediterranean-Style Diet Reduce Heart Disease? Circulation, American Heart Association, 2001, 103: 1821-1822.

[32] Katherine E et al.; Effect of dietary antioxidants on postprandial endothelial dysfunction induced by a high-fat meal in healthy subjects. The American Society for Clinical Nutrition, 2003, 77: 139-143.

[33] Esposito K et al.; Effect of a Mediterranean-style diet on endothelial dysfunction and markers of vascular inflammation in the metabolic syndrome: a randomized trial. JAMA, 2004 292: $1440-1446$. 
[34] Vincent-Baudry S et al.; The Medi-RIVAGE study: reduction of cardiovascular disease risk factors after a 3-mo intervention with a Mediterranean-type diet or a low-fat diet. The American Journal of Clinical Nutrition, 2005, 82: 964-971.

[35] Estruch $\mathrm{R}$ et al.; Effects of a Mediterranean-style diet on cardiovascular risk factors: a randomized trial. Annals of Internal Medicine, 2006, 145: 1-11.

[36] Mente A et al.; A systematic review of the evidence supporting a causal link between dietary factors and coronary heart disease. Archives of Internal Medicine, 2009, 169: 659-669.

[37] Ramón E et al. ; Primary Prevention of Cardiovascular Disease with a Mediterranean Diet. The New England Journal of Medicine, 2013, 368: 1279-1290.

[38] Gorinstein S et al.; Comparison of the bioactive compounds and antioxidant potentials of fresh and cooked Polish, Ukrainian, and Israeli garlic. Journal of Agricultural and Food Chemistry, 2005, 53(7): 2726-32.

[39] Pandino G et al.; Globe artichoke leaves and floral stems as a source of bioactive compounds, Industrial Crops and Products, 2013, 44: 44 - 49 .

[40] Abu-Reidah IM and al.; Extensive characteris-ation of bioactive phenolic constituents from globe artichoke (Cynara scolymus L.) by HPLC-DAD-ESI-QTOF-MS, Food Chemistry, 2013, 141(3): 2269 - 2277.

[41] Ceccarelli $\mathrm{N}$ et al.; Globe artichoke as a functional food, Mediterranean Journal of Nutrition and Metabolism, 2010, 3(3): $197-201$.

[42] Negro D et al.; Polyphenol Compounds in Artichoke Plant Tissues and Varieties, Journal of Food Science, 2012, 77(2): C244 - C252.

[43] Wang $\mathrm{M}$ et al.; Analysis of antioxidative phenolic compounds in artichoke (Cynara scolymus L.). Journal of Agricultural and Food Chemistry 2003, 51(3): 601-608.

[44] Schutz $\mathrm{K}$ et al.; Characterization and quantification of anthocyanins in selected artichoke (Cynara scolymus L.) cultivars by HPLC-DAD-ESI-MS(n). Anal Bioanal Chem 2006: 1-15.

[45] Kaur N, Gupta AK. Applications of inulin and oligofructose in health and nutrition. J Biosci, 2002, 27(7): 703-14.

[46] Wider $\mathrm{B}$ et al.; Artichoke leaf extract for treating hypercholesterolaemia. Cochrane Database of Systematic Reviews, 2009, 7(4): 122-128.

[47] Meyer D and Stasse-Wolthuis M; The bifidogenic effect of inulin and oligofructose and its consequences for gut health. European Journal of Clinical Nutrition, 2009, 63(11): $1277-1289$.

[48] Pool-Zobel BL and Sauer J; Overview of experimental data on reduction of colorectal cancer risk by inulin-type fructans. Journal of Nutrition. 2007, 137(11): 2580S-2584S.

[49] Reena R and Kalidas S; Microwave-induced stimulation of 1-DOPA, phenolics and antioxidant activity in fava bean (Vicia faba) for Parkinson's diet. Process Biochemistry, 2004, 39(11): $1775-1784$.

[50] Kimura $\mathrm{M}$ et al.; $\mathrm{N}$-glycans linked to glycoproteins in edible beans (zatsu-mame): natural resources for bioactive oligosaccharides; Bioscience, biotechnology, and biochemistry, 2011, 75(1): 155 - 158 .
[51] Vadivel V and Biesalski HK ; Bioactive compounds in velvet bean seeds: effect of certain indigenous processing methods; International Journal of Food Properties, 2011, 99999(1): 1.

[52] Campos-Vega R et al.; Chemical Composition and In Vitro Polysaccharide Fermentation of Different Beans (Phaseolus vulgaris L.); Journal of Food Science, 9/2009, 74(7): T59 - T65.

[53] Zhu Z et al.; Edible dry bean consumption (Phaseolus vulgaris L.) modulates cardiovascular risk factors and diet-induced obesity in rats and mice; The British Journal of Nutrition, 2012, 108(S1): S66.

[54] Marisela G et al.; Polyphenols and antioxidant capacity of Phaseolus vulgaris stored under extreme conditions and processed; LWT-Food Science and Technology, 2008, 41(6): 994-999.

[55] Mensack MM et al.; Metabolomic analysis of the effects of edible dry beans (Phaseolus vulgaris L.) on tissue lipid metabolism and carcinogenesis in rats; The British journal of nutrition, 2012, 108(S1): S155.

[56] García-Gasca $\mathrm{T}$ et al.; Effects of Tepary bean (Phaseolus acutifolius) protease inhibitor and semipure lectin fractions on cancer cells; Nutrition and cancer, 2012, 64(8): 1269.

[57] Akillioglu HG and Karakaya S; Changes in total phenols, total flavonoids, and antioxidant activities of common beans and pinto beans after soaking, cooking, and in vitro digestion process; Food Science and Biotechnology, 2010, 19(3): 633-639.

[58] Aparicio-Fernández X et al.; Antiradical capacity and induction of apoptosis on HeLa cells by a Phaseolus vulgaris extract; Plant foods for human nutrition (Dordrecht, Netherlands), 2008, 63(1): $35-40$.

[59] Daniel GF et al.; Evaluation of the antioxidant and antiproliferative activities of extracted saponins and flavonols from germinated black beans (Phaseolus vulgaris L.); Food Chemistry, 2013, 141(2): 1497-1503.

[60] Spadafranca, Angela et al.; Phaseolus vulgaris extract affects glycometabolic and appetite control in healthy human subjects; The British journal of nutrition, 2013, 109(10): 1789.

[61] Matsubara $\mathrm{K}$ et al.; Antiangiogenic activity of nasunin, an antioxidant anthocyanin, in eggplant peels. Journal of Agricultural and Food Chemistry, 2005, 53(16): 6272-6275.

[62] Murthy KNC; Anti-diabetic Potentials of Red Beet Pigments and Other Constituents (Red Beet Biotechnology: Food and Pharmaceutical Applications), 7/2012: 155-174.

[63] Kujala TS et al.; Betalain and phenolic compositions of four beetroot (Beta vulgaris) cultivars. European Food Research and Technology, 2002, 214: 505-10.

[64] Kanner J et al.; Betalains - a new class of dietary cationized antioxidants. Journal of Agricultural and Food Chemistry, 2001, 49(11): 5178-85.

[65] Ribaya-Mercado JD and Blumberg JB. Lutein and zeaxanthin and their potential roles in disease prevention. The Journal of the American College of Nutrition, 2004, 23(6): 567S-87S.

[66] Kapadia GJ et al.; Chemoprevention of lung and skin cancer by Beta vulgaris (beet) root extract. Cancer Lett, 2/1996, 100(1-2): 211-4.

[67] Roberts RL et al.; Lutein and zeaxanthin in eye and skin health. Clin Dermatol, 2009, 27:195-201. 
[68] Váli L et al.; Liver-protecting effects of table beet (Beta vulgaris var. rubra) during ischemia-reperfusion, Nutrition (Burbank, Los Angeles County, Calif.), 2007, 23(2): 172 - 178.

[69] Adel Abdelrazek A et al.; Phenolics Extracted from Potato, Sugar Beet, and Sesame Processing By-Products, International Journal of Food Properties, 2013, 16(5): 1148

[70] Christensen $\mathrm{K}$ et al.; Beneficial effects of carrots (Daucus carota) on adipocyte differentiation, glucose uptake, and fat accumulation, Planta Medica, 2010, 76(12): 632.

[71] Wiczkowski W et al.; Red cabbage anthocyanins: Profile, isolation, identification, and antioxidant activity, Food Research International, 2013, 51(1): 303 - 309.

[72] Nilnakara $S$ et al.; Production of antioxidant dietary fibre powder from cabbage outer leaves, Food and Bioproducts Processing, 2009, 87(4): 301 - 307.

[73] Peñas E et al.; Bioactive compounds, myrosinase activity, and antioxidant capacity of white cabbages grown in different locations of Spain, Journal of agricultural and food chemistry, 2011, 59(8): 3772.

[74] Kusznierewicz B et al.; Partial characteri-zation of white cabbages (Brassica oleracea var. capitata f. alba) from different regions by glucosinolates, bioactive compounds, total antioxidant activities and proteins, Food Science and Technology, 2008, 41(1),: 1-9.

[75] Stoewsand GS; Bioactive organosulfur phytochemicals in Brassica oleracea vegetables: A review, Food and Chemical Toxicology, 1995, 33(6): 537 - 543.

[76] Rungapamestry $\mathrm{V}$ et al.; Changes in glucosinolate concentrations, myrosinase activity, and production of metabolites of glucosinolates in cabbage (Brassica oleracea Var. capitata) cooked for different durations. Journal of Agricultural and Food Chemistry, 2006, 54(20): 7628-34.

[77] Lund E; Non-nutritive bioactive constituents of plants: dietary sources and health benefits of glucosinolates, Nutrition Research, 2003, 73(2): 135-43.

[78] Larsson SC et al.; Fruit and vegetable consumption in relation to pancreatic cancer risk: a prospective study. Cancer Epidemiol Biomarkers Prev, 2006, 15(2):301-5.

[79] Montaut S et al.; Bioactive compounds from crucifers: a beneficial gain in our everyday life, Phytothérapie, 2012, 10(6): $342-349$.

[80] Charron CS et al.; Effect of dose size on bioavailability of acylated and nonacylated anthocyanins from red cabbage (Brassica oleracea L. Var. capitata), Journal of agricultural and food chemistry, 2007, 55(13): 5354-62

[81] Smiechowska A et al.; Cancer chemo-preventive agents: glucosinolates and their decomposition products in white cabbage (Brassica oleracea var. capitata), Post py higieny i medycyny doświadczalnej, 2008, 62: 125 - 140.

[82] Kalpana Deepa Priya D et al.; Apoptotic role of natural isothiocyanate from broccoli (Brassica oleracea italica) in experimental chemical lung carcinogenesis, Pharmaceutical biology, 2013, 51(5): $621-628$

[83] Thejass P and Kuttan G; Immunomodulatory activity of Sulforaphane, a naturally occurring isothiocyanate from broccoli (Brassica oleracea), Phytomedicine, 2007, 14(7): 538 545 .
[84] Kataya HA and Hamza AA; Red Cabbage (Brassica oleracea) Ameliorates Diabetic Nephropathy in Rats, Evidence-based Complementary and Alternative Medicine, 2008, 5(3): 281 287.

[85] Kimura T; Natural products and biological activity of the pharmacologically active cauliflower mushroom Sparassis crispa, BioMed research international, 2013, 2013: 982317.

[86] Takei $\mathrm{T}$ et al.; In situ gellable sugar beet pectin via enzyme-catalyzed coupling reaction of feruloyl groups for biomedical applications, Journal of bioscience and bioengineering, 2011, 112(5): 491.

[87] Nicolle C et al.; Effect of carrot intake on cholesterol metabolism and on antioxidant status in cholesterol-fed rat. European Journal of Nutrition, 2003, 42: 254-261.

[88] Killeen DP et al.; Quantitative Raman Spectroscopy for the Analysis of Carrot Bioactives, Journal of Agricultural and Food Chemistry, 3/2013, 61(11): $2701-2708$.

[89] Zaini R et al.; Bioactive Chemicals from Carrot (Daucus carota) Juice Extracts for the Treatment of Leukemia, Journal of medicinal food, 2011, 14(11): 133 - 1312.

[90] Roman $M$ et al.; Spectroscopic studies on bioactive polyacetylenes and other plant components in wild carrot root, Journal of natural products, 2011, 74(8): 1757 - 1763.

[91] Jasicka-Misiak I et al.; Crotonic acid as a bioactive factor in carrot seeds ( Daucus carota L.), Phytochemistry, 2005, 66(12): $1485-1491$

[92] El-Houri RB and al.; Polyacetylenes from carrots with potential anti-diabetic effects, Planta Medica, 2012, 78(11): PI349.

[93] Sharma KD and al.; Chemical composition, functional properties and processing of carrot - a review, Journal of Food Science and Technology, 2012, 49(1): 22 - 32.

[94] Goveas RN; Are allium vegetables and their constituents associated with reduced risk of breast cancer? 2008: 15-28.

[95] Zohar K et al.; Microwave-assisted extraction of bioactive saponins from chickpea (Cicer arietinum L); Journal of the Science of Food and Agriculture, 2005, 85(3): 406 - 412.

[96] Tan YX et al.; Studies on chemical constituents in seeds of Cicer arietinum, Traditional Chinese Medicine (en chinois), 2007, 32(16): 1650-1652.

[97] $\mathrm{Wu} \mathrm{Z}$ et al.; Germination dramatically increases isoflavonoid content and diversity in chickpea (Cicer arietinum L.) seeds. Journal of agricultural and food chemistry, 2012, 60(35): 8606.

[98] Yolanda A et al.; Phenolic profile and antioxidant capacity of chickpeas (Cicer arietinum L.) as affected by a dehydration process; Plant foods for human nutrition (Dordrecht, Netherlands), 2011, 66(2): 187-19.

[99] Aharon S et al.; Total Phenolic Content and Antioxidant Activity of Chickpea (Cicer arietinum L.) as Affected by Soaking and Cooking Conditions; Food and Nutrition Sciences, 2011, 2(7): 724 - 730.

[100] Nestel P et al.; Effects of long-term consumption and single meals of chickpeas on plasma glucose, insulin, and triacylglycerol concentrations. The American Journal of Clinical Nutrition, 2004, 79(3): 390-395. 
[101] María del Mar Y et al.; Hypocholesterolaemic and antioxidant activities of chickpea (Cicer arietinum L.) protein hydrolysates; Journal of the Science of Food and Agriculture, 2012, 92(9): $1994-2001$.

[102] Nadia A et al.; Attenuation of Chemically Induced Diabetes in Rabbits with Herbal Mixture (Citrullus colocynthis and Cicer arietinum); Pakistan Veterinary Journal, 2013, 33(1): 41 - 44.

[103] Cortés-Giraldo I et al.; Hemagglutinating activity of polyphenols extracts from six grain legumes; Food and chemical toxicology, 2012, 50(6): 1951 - 1954.

[104] Garzón-Tiznado JA et al.; Acceptability Properties and Antioxidant Potential of Desi Chickpea (Cicer arietinum L.) Cultivars; Food and Nutrition Sciences, 2012, 3(9): 1281.

[105] Queiroz-Monici DS et al. ; Bifidogenic effect of dietary fiber and resistant starch from leguminous on the intestinal microbiota of rats. Nutrition, 2005, 21(5): 602-608.

[106] Guzman I et al.; Simultaneous extraction and quantitation of carotenoids, chlorophylls, and tocopherols in Brassica vegetables, Journal of agricultural and food chemistry, 2012, 60(29): 7238

[107] Abu-Reidah IM et al.; HPLC-ESI-Q-TOF-MS for a comprehensive characterization of bioactive phenolic compounds in cucumber whole fruit extract, Food Research International, 2012, 46(1): 108 - 117.

[108] Mukherjee PK et al.; Phytochemical and therapeutic potential of cucumber, Fitoterapia, 2013, 84: 227.

[109] Nema NK et al., Cucumis sativus fruit-potential antioxidant, anti-hyaluronidase, and anti-elastase agent, Archives of Dermatological Research, 2011, 303: 247-252.

[110] Sotiroudis G et al.; Chemical analysis, antioxidant and antimicrobial activity of three Greek cucumber (Cucumis sativus) cultivars, Journal of Food Biochemistry, 2010, 34: 61-78.

[111] Gill NS et al.; Evaluation of antioxidant and antiulcer potential of Cucumis sativus L. seed extract in rats, Asian J Clin Nutr, 2009, 1: 131-138.

[112] Hogade MG et al.; Comperitive sun protection factor determination of fresh fruit extract of Cuccumber vs marketed cosmetic formulation, Res Pharm Biol Chem Sci, 2010, 1: $55-59$.

[113] Dixit Y and Kar A; Protective role of three vegetable peels in alloxan induced diabetes mellitus in male mice. Plant Foods for Human Nutrition, 2010, 65: 284-289.

[114] Kelly G; Inulin-type prebiotics: a review. (Part 2). Altern Med Rev. 2009, 14(1): 36-55.

[115] Giuseppe $\mathrm{M}$ and al.; Chemical and bioactive quality traits during fruit ripening in eggplant (S. melongena L.) and allied species, Journal of agricultural and food chemistry, 11/2012, 60(47): 11821.

[116] Upadhyay R et al.; An outlook on chlorogenic acids-occurrence, chemistry, technology, and biological activities, Critical reviews in food science and nutrition, 2013, 53(9): 968.

[117] Mariola et al.; Breeding for Chlorogenic Acid Content in Eggplant: Interest and Prospects, Notulae Botanicae Horti Agrobotanici Cluj-Napoca, 2013, 41(1): 26 - 35.
[118] Ichiyanagi T et al.; Nasunin from eggplant consists of cis-trans isomers of delphinidin 3-[4-(p-coumaroyl)-L-rhamnosyl (1-->6)glucopyranoside]-5-glucopyranoside. Journal of Agricultural and Food Chemistry, 2005, 53(24): 9472-9477.

[119] Luthria DL; A simplified UV spectral scan method for the estimation of phenolic acids and antioxidant capacity in eggplant pulp extracts, Journal of Functional Foods, 2012, 4(1): $238-242$.

[120] Sudheesh S et al.; Hypolipidemic effect of flavonoids from Solanum melongena. Plant Foods for Human Nutrition, 1997, 51(4): 321-30.

[121] Noda $\mathrm{Y}$ et al.; Antioxidant activity of nasunin, an anthocyanin in eggplant peels. Toxicology, 2000, 148(2-3): 119-23.

[122] Nadia C et al.; Polyphenols content and antioxidant capacity of thirteen faba bean (Vicia faba L.) genotypes cultivated in Tunisia, Food Research International, 2011, 44(4): 970-977.

[123] Merghem R et al.; Qualitative analysis and HPLC isolation and identification of procyanidins from Vicia faba, Phytochemical analysis: PCA, 3/2004, 15(2): 95 - 99.

[124] Shetty Ket al.; Effects of UV treatment on the proline-linked pentose phosphate pathway for phenolics and L-DOPA synthesis in dark germinated Vicia faba, Process Biochemistry, 2002, 37(11): 1285-1295.

[125] Cardador-Martínez Aet al.; Effect of Roasting and Boiling on the Content of Vicine, Convicine and L-3,4-dihydroxyphenylalanine in Vicia faba L; J Food Quality, 12/2012, 35(6): 419 - 428.

[126] Randhir R et al., 1-DOPA and total phenolic stimulation in dark germinated fava bean in response to peptide and phytochemical elicitors; Process Biochemistry, 2002, 37(11): 1247 - 1256.

[127] Angelis A et al., Efficient isolation of bioactive constituents from Greek Fabaceae species through elaboration of counter-current chromatography (CCC) approaches; Planta Med, 2011, 77: 65.

[128] Macarulla MT et al.; Effects of the whole seed and a protein isolate of faba bean (Vicia faba) on the cholesterol metabolism of hypercholesterolaemic rats. British Journal of Nutrition, 2001, 85(5): 607-14.

[129] Apaydin H et al.; Broad bean (Vicia faba)--a natural source of L-dopa--prolongs "on" periods in patients with Parkinson's disease who have "on-off" fluctuations. Movement Disorders Journal, 2000, 15(1): 164-166.

[130] Ladha SS et al.; Case of neuroleptic malignant-like syndrome precipitated by abrupt fava bean discontinuance. Movement Disorders Journal, 2005, 20(5): 630-631.

[131] Rabey JM et al.; Improvement of parkinsonian features correlate with high plasma levodopa values after broad bean (Vicia faba) consumption. J Neurol Neurosurg Psychiatry, 1992, 55(8): 725-727.

[132] Pastor $\mathrm{C}$ et al., antioxidative activity in the seeds of 28 vicia species from southern spain; Journal of Food Biochemistry, 2011, 35(5): 1373 - 1380.

[133] Reena R and Kalidas S; Microwave-induced stimulation of 1-DOPA, phenolics and antioxidant activity in fava bean (Vicia faba) for Parkinson's diet; Process Biochemistry, 2004, 39(11): 1775-1784. 
[134] Lanzotti V; Bioactive polar natural compounds from garlic and onions, Phytochemistry Reviews, 2012, 11(2): 179 - 196.

[135] Matsuura H; Saponins in garlic as modifiers of the risk of cardiovascular disease. Journal of Nutrition, 2001, 131(3S): 1000S-5S.

[136] Brace LD; Cardiovascular benefits of garlic (Allium sativum L). Journal of Cardiovascular Nursing., 2002, 16(4): 33-49.

[137] Hsing AW et al.; Allium vegetables and risk of prostate cancer: a population-based study. Journal of the National Cancer Institute, 2002, 94(21): 1648-1651.

[138] Fleischauer AT et al.; Garlic consumption and cancer prevention: meta-analyses of colorectal and stomach cancers. The American Journal of Clinical Nutrition, 2000, 72(4): 1047-52.

[139] El-Batal AI et al.; Gamma radiation mediated green synthesis of gold nanoparticles using fermented soybean-garlic aqueous extract and their antimicrobial activity, SpringerPlus, 2013, 2(1): $1-10$.

[140] Khanum F et al.; Anticarcinogenic properties of garlic: a review. Critical Reviews in Food Science and Nutrition, 2004, 44(6): 479-88.

[141] Franca B and Harri V ; Allium Vegetables and Organosulfur Compounds: Do They Help Prevent Cancer? Environmental Health Perspectives, 2001, 109(9): 893-902.

[142] Béliveau R et Gingras D ; Les aliments contre le cancer. La prévention et le traitement du cancer par l'alimentation. Éd. du Trécarré, Canada, 2005: 3-21.

[143] Maria K et al.; Composition and properties of biologically active pectic polysaccharides from leek (Allium porrum); Journal of the science of food and agriculture, 2010, 90(12): 2046.

[144] Fattorusso E et al.; The flavonoids of leek, Allium porrum. Phytochemistry, 2001, 57(4): 565-569.

[145] Fattorusso E et al.; Cytotoxic saponins from bulbs of Allium porrum L. Journal of Agricultural and Food Chemistry, 2000, 48(8): 3455-3462.

[146] Carotenuto A et al.; Porrigenins A and B, novel cytotoxic and antiproliferative sapogenins isolated from Allium porrum. $\mathrm{J}$ Nat Prod, 1997, 60(10): 1003-1007.

[147] Mehmet O et al.; Effect of Dehydration on Several Physico-Chemical Properties and the Antioxidant Activity of Leeks (Allium porrum L.); Notulae Botanicae Horti Agrobotanici Cluj-Napoca, 2011, 39(1): 144 - 151.

[148] Rose P et al. ; Bioactive S-alk(en)yl cysteine sulfoxide metabolites in the genus Allium: the chemistry of potential therapeutic agents. Natural Product Reports, 2005, 22(3): 351-368.

[149] Goveas RN; Are allium vegetables and their constituents associated with reduced risk of breast cancer? 2008: 15-28.

[150] Mo'ez Al-Islam EF et al.; Role of lentils ( Lens culinaris L.) in human health and nutrition: a review; Mediterranean Journal of Nutrition and Metabolism, 2013, 6(1): 3-16.

[151] Dalaram SI et al.; bioactive compounds in commonly utilized legume cultivars from iraq; Journal of Microbiology, Biotechnology and Food Sciences, 2013, 2: 2032 - 2042.
[152] Inés TM et al.; Antioxidant and antihy-pertensive properties of liquid and solid state fermented lentils; Food chemistry, 2013, 136(2): 1030

[153] Mo'ez Al-Islam EF et al.; Chemopreventive effect of raw and cooked lentils ( Lens culinaris L) and soybeans (Glycine max) against azoxymethane-induced aberrant crypt foci; Nutrition Research, 2009, 29(5): 355 - 362.

[154] Takeoka GR et al. Delphinidin 3-O-(2-O-beta-D-Glucopyranosyl-alpha-l-arabinopyranoside): a novel anthocyanin identified in Beluga black lentils. Journal of Agricultural and Food Chemistry, 2005, 53(12): 4932-4937.

[155] Amarowicz $\mathrm{R}$ et al.; Free radical-scavenging capacity, antioxidant activity, and phenolic composition of green lentil (Lens culinaris). Food Chem, 2010, 121: 705-711.

[156] Oomah BD et al.; Phenolics and antioxidant activity of lentil and pea hulls. Food Res Int, 2011, 44: 436-441.

[157] Boye JI et al.; Angiotensin I-converting enzyme inhibitory properties and SDS-PAGE of red lentil protein hydrolysates. LWT- Food Science Technology, 2010, 43: 987-991.

[158] Shams H et al.; Effects of cooked lentils on glycaemic control and blood lipids of patients with type 2 diabetes. ARYA Atherosclerosis Journal, 2008, 3: 215-218.

[159] Al-Tibi AMH et al.; Effect of dehulling and cooking of lentils (Lens culinaris L.) on serum glucose and lipoprotein levels in streptozotocin-induced diabetic rats. Malays J Nutr, 2010, 16:83-92.

[160] Alexandre KB et al.; Mannose-rich glycosylation patterns on HIV-1 subtype C gp120 and sensitivity to the lectinsGriffithsin- Cyanovirin-N and Scytovirin. Journal of Virology, 2010, 402: 187-196.

[161] Ramdath DD and Tsao R; Bioactives and Health Benefits of Lentils (Lens culinaris L.); Cereals and Pulses: Nutraceutical Properties and Health Benefits (1st Ed), John Wiley \& Sons, Inc., 2012: 217-228.

[162] Cruz R et al.; Carotenoids of lettuce (Lactuca sativa L.) grown on soil enriched with spent coffee grounds; Molecules (Basel, Switzerland), 2012, 17(2): 1535 - 1547.

[163] Ribas-Agustí A et al.; Analysis of Eleven Phenolic Compounds Including Novel p-Coumaroyl Derivatives in Lettuce (Lactuca sativa L.) by Ultra-high-performance Liquid Chromatography with Photodiode Array and Mass Spectrometry Detection. Phytochem Anal. 2011.

[164] Im SE et al. Antineurodegenerative Effect of Phenolic Extracts and Caffeic Acid Derivatives in Romaine Lettuce on Neuron-Like PC-12 Cells. J Med Food, 8/2010, 13(4): 779-84.

[165] Marouane B et al.; Nutritional quality of outer and inner leaves of green and red pigmented lettuces (Lactuca sativa L.) consumed as salads; Scientia Horticulturae, 2/2013, 151: 103-111.

[166] Anna S et al.; Root tubers of Lactuca tuberosa as a source of antioxidant phenolic compounds and new furofuran lignans; Food Chemistry, 6/2013, 138(2-3): 1250-1255.

[167] Edziri HL et al.; Antioxidant, antibacterial, and antiviral effects of Lactuca sativa extracts; Industrial Crops and Products, 2011, 34(1): 1182-1185. 
[168] Siddiq M et al.; Total phenolics, antioxidant properties and quality of fresh-cut onions (Allium cepa L.) treated with mild-heat; Food Chemistry, 2013, 136(2): 803-806.

[169] Hang X; Identification of bioactive agents from green onion (Allium spp.) and organoselenium compounds with cancer chemopreventive potential; 2004: 383.

[170] Lanzotti V; Bioactive polar natural compounds from garlic and onions; Phytochemistry Reviews, 2012, 11(2): 179-196.

[171] Eduvigis R et al.; Characterisation of onion (Allium cepa L.) by-products as food ingredients with antioxidant and antibrowning properties; Food Chemistry, 2008, 108(3): 907 916.

[172] Griffiths G et al.; Onions--a global benefit to health. Phytotherapy Research, 2002, 16(7):603-615.

[173] Yang J; Varietal differences in phenolic content and antioxidant and antiproliferative activities of onions; Journal of agricultural and food chemistry, 2004, 52(22): 6787 - 6793.

[174] Attila M and Juliana M; Use of onion extracts to prevent and treat acute and chronic cardiac and vascular complications and their sequelae, as well as to resolve hematomas, 2009: 112.

[175] Galeone C et al. ; Onion and garlic use and human cancer. The American Journal of Clinical Nutrition, 2006, 84(5): 1027-1032.

[176] Hu J et al. ; Diet and brain cancer in adults: a case-control study in northeast China. Int J Cancer, 1999, 81(1): 20-23.

[177] Shon M-Y et al. ; Antimutagenic, antioxidant and free radical scavenging activity of ethyl acetate extracts from white, yellow and red onions. Food and chemical toxicology, 2004, 42: 659-666.

[178] Gabler NK et al.; Dietary onion intake as part of a typical high fat diet improves indices of cardiovascular health using the mixed sex pig model. Plant Foods for Human Nutrition, 2006, 61(4): 179-185.

[179] Hubbard GP et al.; Ingestion of onion soup high in quercetin inhibits platelet aggregation and essential components of the collagen-stimulated platelet activation pathway in man: a pilot study. British Journal of Nutrition, 2006, 96(3): 482-488.

[180] Chun-Lin Ye et al.; Antimicrobial and antioxidant activities of the essential oil from onion (Allium cepa L.); Food Control, 2013, 30(1): 48-53.

[181] Uthman AY et al.; Allium cepa Protects Renal Functions in Diabetic Rabbits; World Journal of Life Sciences and Medical Research, 2012, 2(2): 81.

[182] Samson OA et al.; Functional properties of yellow field pea (Pisum sativum L.) seed flours and the in vitro bioactive properties of their polyphenols. Food Research International, 2010, 43(2): 582-588.

[183] Rubén A et al.; Thermal treatment improves nutritional quality of pea seeds (Pisum sativum L.) without reducing their hypocholesterolemic properties; Nutrition Research, 2001, 21(7): 1067-1077.

[184] Nilsson $\mathrm{J}$ et al.; Total antioxidant capacity in different pea (Pisum sativum) varieties after blanching and freezing. Food Chemistry, 2004, 86(4): 501-507.
[185] Nithiyanantham S et al.; Total phenolic content and antioxidant activity of two different solvent extracts from raw and processed legumes, Cicer arietinum L. and Pisum sativum L. Journal of Food Composition and Analysis, 2012, 27(1): 52-60.

[186] Lim TK; Pisum sativum; Edible Medicinal and Non-Medicinal Plants - Fruits. Vol. 2; Springer Netherlands, 2012: 849-866.

[187] Han H and Byung-Kee B; Antioxidant activity and phenolic content of lentils (Lens culinaris), chickpeas (Cicer arietinum L.), peas (Pisum sativum L.) and soybeans (Glycine max), and their quantitative changes during processing. International Journal of Food Science \& Technology, 2008, 43(11): 1971-1978.

[188] Duenas M et al.; Occurrence of phenolic compounds in the seed coat and the cotyledon of peas (Pisum sativum L.). European Food Research and Technology, 2004, 219(2): 116-123.

[189] Alfonso C et al.; The anti-proliferative effect of TI1B, a major Bowman-Birk isoinhibitor from pea (Pisum sativum L.), on HT29 colon cancer cells is mediated through protease inhibition; The British journal of nutrition, 2012, 108(S1): S135.

[190] Sadia R et al. ; Synthesis and in-vitro antimicrobial screening of 3-cinnamoyl coumarin and 3-[3-(1H-indol-2-yl)-3-aryl-propanoyl]-2H-chromen-2-ones. Iranian Journal of Catalysis, 2013, 3(3): 171-176.

[191] Thompson HJ et al.; Functional food characteristics of potato cultivars (Solanum tuberosum L.): Phytochemical composition and inhibition of 1-methyl-1-nitrosourea induced breast cancer in rats; J Food Composition and Analysis, 2009, 22(6): 571-576.

[192] Tudela JA et al.; Induction of antioxidant flavonol biosynthesis in fresh-cut potatoes. Effect of domestic cooking. Journal of Agricultural and Food Chemistry, 2002, 50(21): 5925-5931.

[193] Xu X et al.; Phenolic content, composition, antioxidant activity, and their changes during domestic cooking of potatoes. Journal of Agricultural and Food Chemistry, 2009, 57: 10231-10238.

[194] David C et al.; Antioxidant capacity and secondary metabolites in four species of Andean tuber crops: native potato (Solanum sp.), mashua (Tropaeolum tuberosum Ruiz \& Pavón), Oca (Oxalis tuberosa Molina) and ulluco (Ullucus tuberosus Caldas); J Science of Food and Agriculture, 2006, 86(10): $1481-1488$.

[195] Han KH et al.; Anthocyanin-rich purple potato flake extract has antioxidant capacity and improves antioxidant potential in rats. British Journal of Nutrition, 2006, 96(6):1125-1133.

[196] Barbara B et al.; Nutrients, bioactive non-nutrients and anti-nutrients in potatoes; Journal of Food Composition and Analysis, 2011, 22(6): 494 - 502.

[197] Verde Mendez CM et al.; Content of free phenolic compounds in cultivars of potatoes harvested in Tenerife (Canary Islands). Journal of Agricultural and Food Chemistry, 2004, 52(5): 1323-1327.

[198] Kaspar KL et al.; Pigmented potato consumption alters oxidative stress and inflammatory damage in men. J Nutr, 2011, 141:108-111.

[199] Kaspar KL et al.; Processing of pigmented-flesh potatoes (Solanum tuberosum L.) on the retention of bioactive compounds; International Journal of Food Science \& Technology, 2012, 47(2): 376 - 382. 
[200] Im HW et al.; Analysis of phenolic compounds by high-performance liquid chromatography and liquid chromatography/mass spectrometry in potato plant flowers, leaves, stems, and tubers and in home-processed potatoes. Journal of Agricultural and Food Chemistry, 2008, 56: 3341-3349.

[201] Hashimoto N et al.; Potato pulps lowered the serum cholesterol and triglyceride levels in rats. Journal of Nutritional Science and Vitaminology, 2006, 52(6): 445-450.

[202] Reddivari L et al.; Specialty Potatoes (Solanum Tuberosum L.) as a Source of Bioactive Compounds to Reduce Human Prostate Cancer Cell Proliferation in Vitro; 89th Annual Meeting of the Potato Association of America, 2005: 1-25.

[203] Anne P et al.; ACE-inhibitory and antioxidant properties of potato (Solanum tuberosum); Food Chemistry, 2008, 109(1): $104-112$.

[204] Lavanya R et al.; The bioactive compounds alpha-chaconine and gallic acid in potato extracts decrease survival and induce apoptosis in LNCaP and PC3 prostate cancer cells; Nutrition and cancer, 2010, 62(5): 601 .

[205] Dorota G et al.; Characterisation of five potato cultivars according to their nutritional and pro-health components; Acta scientiarum polonorum. Technologia alimentaria, 2011, 10(1): $77-81$.

[206] Gaurav PM et al.; Storage elevates phenolic content and antioxidant activity but suppresses antiproliferative and pro-apoptotic properties of colored-flesh potatoes against human colon cancer cell lines. Journal of agricultural and food chemistry, 2011, 59(15): 8155.

[207] Ji X et al.; Quantitative Analysis of Phenolic Components and Glycoalkaloids from 20 Potato Clones and in vitro Evaluation of Antioxidant, Cholesterol uptake, and Neuroprotective Activities; Food Chemistry, 2011, 133(4): 1177.

[208] Akhilesh K et al.; Traditional uses of medicinal plants for dermatological healthcare management practices by the Tharu tribal community of Uttar Pradesh, India; Genetic Resources and Crop Evolution, 2013, 60(1): 203-224.

[209] Battistuzzi G et al.; Characterization of the solution reactivity of a basic heme peroxidase from Cucumis sativus. Archives of Biochemistry and Biophysics, 2004, 423(2): 317-31.

[210] Lee BH et al.; Comparison of the chemical compositions and nutritive values of various pumpkin (Cucurbitaceae) species and parts, Nutrition Research and Practice, 2012, 6(1): 21.

[211] Veronezi CM and Jorge N; Bioactive compounds in lipid fractions of pumpkin (Cucurbita $\mathrm{sp}$ ) seeds for use in food, Journal of food science, 6/2012, 77(6): C653 - C657.

[212] Caili $\mathrm{F}$ et al.; A review on pharmacological activities and utilization technologies of pumpkin. Plant Foods for Human Nutrition, 2006, 61(2): 73-80.

[213] Quanhong L et al.; Effects of protein-bound polysaccharide isolated from pumpkin on insulin in diabetic rat. Plant Foods for Human Nutrition, 2005, 60(1) :13-6.

[214] Vaštag, Z et al.; In vitro study on digestion of pumpkin oil cake protein hydrolysate: evaluation of impact on bioactive properties, International journal of food sciences and nutrition, 2013, 64(4): 452.
[215] Young KM et al.; Comparison of the chemical compositions and nutritive values of various pumpkin (Cucurbitaceae) species and parts, Nutrition research and practice, 2012, 6(1): $21-27$.

[216] Mukesh Y et al.; Medicinal and biological potential of pumpkin an updated review, Nutrition Research Reviews, 2010, 23(2): 184-190.

[217] Gary GA et al.; The hypoglycaemic effect of pumpkins as anti-diabetic and functional medicines, Food Research International, 2011, 44(4): 862 - 867

[218] Francisca H et al.; Chemical Properties of Pumpkin Dried by Different Methods, Hrvatski Casopis za Prehrambenu Tehnologiju, Biotehnologiju i Nutricionizam, 2012, 7(1-2): 98.

[219] Jayaprakasam B et al.; Anticancer and antiinflammatory activities of cucurbitacins from Cucurbita andreana. Cancer Lett, 2003, 189(1): 11-6.

[220] Chen JC et al.; Cucurbitacins and cucurbitane glycosides: structures and biological activities. Natural Product Reports, 6/2005, 22(3): 386-99

[221] Alarcon-Aguilar FJ et al.; Evaluation of the hypoglycemic effect of Cucurbita ficifolia Bouche (Cucurbitaceae) in different experimental models. Journal of Ethnopharmacology, 2002, 82(2-3): 185-9.

[222] Akhilesh $\mathrm{K}$ et al.; Traditional uses of medicinal plants for dermatological healthcare management practices by the Tharu tribal community of Uttar Pradesh, India; Genetic Resources and Crop Evolution, 2013, 60(1): 203-224.

[223] Blažević I and Mastelić J; Glucosinolate degradation products and other bound and free volatiles in the leaves and roots of radish (Raphanus sativus L.); Food Chemistry, 2009, 113(1): 96 $-102$.

[224] Otsuki $\mathrm{T}$ et al. ; Acylated anthocyanins from red radish (Raphanus sativus L.). Phytochemistry, 2002, 60(1):79-87.

[225] Castro-Torres A et al.; Antilithiasic and Hypolipidaemic Effects of Raphanus sativus L. var. niger on Mice Fed with a Lithogenic Diet; Journal of biomedicine \& biotechnology, 2012 2012: 161205 .

[226] Kang JH et al. ; Fruit and vegetable consumption and cognitive decline in aging women. Ann Neurol, 2005, 57(5):713-720.

[227] De Nicola, Gina Rosalinda et al.; Comparison of bioactive phytochemical content and release of isothiocyanates in selected brassica sprouts; Food chemistry, 2013, 141(1): 297.

[228] Masakazu H et al.; Variations in the soluble sugar and organic acid contents in radish (Raphanus sativus L.) cultivars; International Journal of Food Science \& Technology, 2011, 46(11): 2387-2392.

[229] Lugasi A et al.; Antioxidant effect of squeezed juice from black radish (Raphanus sativus L. var niger) in alimentary hyperlipidaemia in rats. Phytotherapy Research, 2005, 19(7): 587-591.

[230] Sipos P et al.; Effects of black radish root (Raphanus sativus L. var niger) on the colon mucosa in rats fed a fat rich diet. Phytotherapy Research, 2002, 16(7):677-9.

[231] Salah-Abbès $\mathbf{J}$ et al.; Raphanus sativus extract prevents and ameliorates zearalenone-induced peroxidative hepatic damage in Balb/c mice; Journal of pharmacy and pharmacology, 2009, 61(11): 1545 - 1554 
[232] Rakhmawati R et al.; Potency of Lobak Leaves (Raphanus sativus L. var. hortensis Back) as Anticancer and Antimicrobial Candidates; Biodiversitas, 2009, 10(3): 158 - 162.

[233] Ciska E et al.; Content of glucosinolates in cruciferous vegetables grown at the same site for two years under different climatic conditions. Journal of Agricultural and Food Chemistry, 2000, 48(7): 2862-2867.

[234] Nakamura Y et al.; 4-(Methylthio)-3-butenyl isothiocyanate, a principal antimutagen in daikon (Raphanus sativus; Japanese white radish). Journal of Agricultural and Food Chemistry, 2001, 49(12): 5755-5760.

[235] Suh SJ et al.; Raphanus sativus and its isothiocyanates inhibit vascular smooth muscle cells proliferation and induce $\mathrm{G}(1)$ cell cycle arrest. Int Immunopharmacol, 2006, 6(5): 854-861.

[236] Martínez-Villaluenga $\mathrm{C}$ et al.; Food safety evaluation of broccoli and radish sprouts; Food and Chemical Toxicology, 2008, 46(5): 1635 - 1644.

[237] De Nicola GR et al.; Brassicaceae sprouts as a source of compounds beneficial to health; Journal of Biotechnology, 2010, 150: 300 .

[238] Gilani AH and Ghayur MN; Pharmacological basis for the gut stimulatory activity of Raphanus sativus leaves. Journal of Ethnopharmacology, 2004, 95(2-3): 169-172.

[239] Jeong SI et al. ; Methylisogermabullone isolated from radish roots stimulates small bowel motility via activation of acetylcholinergic receptors. Journal of Pharmacology and Pharmacotherapeutics, 2005, 57(12): 1653-1659.

[240] Shivapriya M et al.; Crucial facts about health benefits of popular cruciferous vegetables; Journal of Functional Foods, 2012, 4(1): 94 - 106.

[241] Bansal, P et al.; Cruciferous Vegetables: Novel Cancer Killer and Guardians of Our Health (1st ed); 2012: 1-25.

[242] Sandi LN; Cruciferous Vegetables and Biomarkers of Systemic Inflammation in a Controlled Feeding Trial in Humans: Effects of GST Genotype (thesis); 2011: 1-9.

[243] Marta F et al., Cooking methods of Brassica rapa affect the preservation of glucosinolates, phenolics and vitamin C; Food Research International, 2010, 43(5): 1455 - 1463.

[244] Alfredo A et al.; Seasonal effects on bioactive compounds and antioxidant capacity of six economically important brassica vegetables; Molecules (Basel, Switzerland), 2011, 16(8): 6816 -6832 .

[245] Carla S et al.; Inflorescences of Brassicacea species as source of bioactive compounds: A comparative study; Food Chemistry, 2008, 110(4): 953 - 961.

[246] Szydłowska-Czerniak A; Rapeseed and its products--sources of bioactive compounds: a review of their characteristics and analysis; Critical reviews in food science and nutrition, 2013, 53(4): 307.

[247] Hwang ES and Lee HJ; Phenylethyl isothiocyanate and its $\mathrm{N}$-acetylcysteine conjugate suppress the metastasis of SK-Hep1 human hepatoma cells. The Journal of Nutritional Biochemistry, 2006, 11(5): 122-128.

[248] Romani A et al.; HPLC-DAD/MS characte-rization of flavonoids and hydroxycinnamic derivatives in turnip tops (Brassica rapa L. Subsp. sylvestris L.). Journal of Agricultural and Food Chemistry, 2006, 54(4): 1342-1346.
[249] Bosetti C et al.; A pooled analysis of case-control studies of thyroid cancer. VII. Cruciferous and other vegetables (International). Cancer Causes Control, 2002, 13(8): 765-775.

[250] Cartea ME et al.; Glucosinolate Variation in Leaves of Brassica rapa Crops; Plant Foods for Human Nutrition, 2012, 67(3): 283 -288 .

[251] Monika S et al.; Enhanced glucosinolates in root exudates of Brassica rapa ssp. rapa mediated by salicylic acid and methyl jasmonate; Journal of agricultural and food chemistry, 2011, 59(4): 1400.

[252] Cynthia AT et al. ; cruciferous Vegetables, Isothiocyanates, Indoles, and Cancer Prevention, Nutrition and Health: Bioactive Compounds and Cancer, 2010: 535-566.

[253] Fowke JH; Head and neck cancer: a case for inhibition by isothiocyanates and indoles from cruciferous vegetables, European journal of cancer prevention: the official journal of the European Cancer Prevention Organisation (ECP), 2007, 16(4): 348-356.

[254] Bonnesen C et al.; Dietary indoles and isothiocyanates that are generated from cruciferous vegetables can both stimulate apoptosis and confer protection against DNA damage in human colon cell lines; Cancer research, 2001, 61(16): 6120-6130.

[255] Cos P et al.; Proanthocyanidins in health care: current and new trends. Current Medicinal Chemistry, 2004, 11(10): $1345-1359$.

[256] Simin L; Book Review: Mediterranean Diet. The American Journal of Clinical Nutrition, 2001, 73: 847.

[257] David MK; Introduction to the Philosophy of Food. University of California Press, 2012: 1-23.

[258] Keys A ; Mediterranean diet and public health: personal reflections. The American Society for Clinical Nutrition, 1995, 61(Suppl): 1321S-1323S.

[259] Alexandratos N; The Mediterranean diet in a world context. Public Health Nutrition: 2006, 9(1A): 111-117.

[260] Dietary Guidelines for Americans, U.S. Department of Agriculture and U.S. Department of Health and Human Services. Washington, DC: U.S. Government Printing Office, 2010: 112 p.

[261] Eating Well with Canada's Food Guide, Ministry of Health, Canada. 2011: 6p.

[262] Food-Based Dietary Guidelines in Europe (FBDG), European Food Safety Authority (EFSA), 2009: 31p.

[263] Eat for Health: Australian Dietary Guidelines, Providing the scientific evidence for healthier Australian diets. National Health and Medical Research Council (NHMRC) Commonwealth of Australia. 2013: 226p.

[264] Dietary Reference Intakes for Japanese (DRIs-J), Ministry of Health, Labour and Welfare, 2010. In: Journal of Nutritional Science and Vitaminology, 2013, 59(suppl): S1-S109.

[265] Diet, Nutrition and the Prevention of Chronic Diseases, WHO Technical Report Series No 916. 2003: 160p.

[266] David Heber; What Color is Your Diet? Harper Collins, 2002: 288p.

[267] Anonymous; Color code your lunch. Current Health 1, 2001, 25(1): 2 . 
[268] Heber D; Vegetables fruits and phytoestrogens in the prevention of diseases. Journal of Postgraduate Medicine, 8/2004, 50(2): 145-149.

[269] Walsh J; Colorful diet helps keep cancer at bay: Fruits and vegetables are key, Environmental Nutrition, 2001, 24(6): 1.

[270] Barnes S et al.; In nutrition, can we "see" what is good for us? Advances in Nutrition, 2013, 4: 327S-334S.

[271] Gaine PC et al. ; Are dietary bioactives ready for recommended intakes? Advances in Nutrition, 9/2013, 4(5): 539-541.

[272] Blumberg JB; Cranberries and Their Bioactive Constituents in Human Health. Advances in Nutrition, 2013, 4: 618-632.

[273] Solomon HK and William WW ; Bioactive Food Components, Encyclopedia of Food \& Culture (2nd Ed); Acceptance to Food Politics, B Letter, Charles Scribner's Sons , 2003, 1: 201-205.

[274] Nicoli MC et al.; Influence of processing on the antioxidant properties of fruit and vegetables. Trends in Food Science and Technology, 1999, 10: 94-100.

[275] Jones RB et al. ; A review of the influence of postharvest treatments on quality and glucosinolate content in broccoli (Brassica oleracea var. italica) heads. Postharvest Biology and Technology, 2006, 41, 1-8.

[276] Slavin JL et al.; Grain processing and nutrition. Critical Reviews in Biotechnology, 2001, 21(1): 49-66.

[277] Mori K et al. ; Loss of anthocyanins in red-wine grape under high temperature. Journal of Experimental Botany, 2007, 58(8): 1935-1945.

[278] Palma M et al.; Stability of phenolic compounds during extraction with superheated solvents. Journal of Chromatography A, 2001, 921: 169-174.

[279] Pérez-Conesa D et al. ; Changes in bioactive compounds and antioxidant activity during homogenization and thermal processing of tomato puree. Innov Food Sci Eng Technol, 2009, 10: 179-188.

[280] Shen YC et al. ; Contribution of tomato phenolics to antioxidation and down-regulation of blood lipids. Journal of Agricultural and Food Chemistry, 2007, 55: 6475-6481.

[281] Heredia JB and Cisneros-Zevallos L; The effect of exogenous ethylene and methyl jasmonate on pal activity, phenolic profiles and antioxidant capacity of carrots (Daucus carota) under different wounding intensities. Postharvest Biology and Technology, 2009, 51(2): 242-249.

[282] Ruiz-Cruz S et al. ; Sanitation procedure affects biochemical and nutritional changes of shredded carrots. Journal of Food Science, 2007, 72(2): S146-S152.

[283] Hager TJ and Howard LR ; Processing effects on carrot phytonutrients. Hortscience, 2006, 41(1): 74-79.

[284] Awuah GB et al. ; Thermal processing and quality: Principles and overview. Chemical Engineering and Processing, 2007, 46: 584-602.

[285] Kays SJ and Paull RE ; Postharvest Biology, Atlanta Georgia: Exon Press, 2004: 568p.
[286] Tiwari BK et al. ; Non thermal processing. In: Handbook of Plant Food Phytochemicals: Sources, Stability and Extraction (1st Ed). John Wiley \& Sons, 2013: 273-299.

[287] Naczk M and Shahidi F ; Phenolics in cereals, fruits and vegetables: occurrence, extraction and analysis. J Pharm Biomed Anal, 2006, 41:1523-1542.

[288] Song LJ et al. ; Purification of major glucosinolates from Brassicaceae seeds and preparation of isothiocyanate and amine metabolites. Journal of the Science of Food and Agriculture, 2006, 86(8): 1271-1280.

[289] Marín A et al. ; Characterization and quantification of antioxidant constituents of sweet pepper (Capsicum annuum L.). Journal of Agricultural and Food Chemistry, 2004, 52: 3861-3869.

[290] Bordiga M et al.; Characterisation of polymeric skin and seed proanthocyanidins during ripening in six Vitis vinifera L. cv. Food Chem, 2011, 127(1): 180-187.

[291] Anttonen MJ and Karjalainen RO; Environmental and genetic variation of phenolic compounds in red raspberry; Journal of Food Composition and Analysis, 2005, 18(8): 759-769.

[292] Negi PS ; Plant extracts for the control of bacterial growth: Efficacy, stability and safety issues for food application. International journal of Food Microbiology, 2012, 156(1): $7-17$.

[293] Scott H et al. ; Food allergy. J Allergy Clin Immunol., 2010, 125(2): S116-S125.

[294] Anonymous; Guidance on Food Allergen Management for Food Manufacturers. FoodDrinkEurope, Belguim, 2013: 85p.

[295] Keeton RW et al. ; Pharmacologic Food Reactions: Food Allergy: Adverse Reactions to Foods and Food Additives (Chapter 35). Blackwell Publishing Ltd. (4th Ed), 2008: 430-442.

[296] Singh J and Kaur L ; Advances in potato chemistry and technology: Analysis and Biological Activities of Potato Glycoalkaloids, Calystegine Alkaloids, Phenolic Compounds, and Anthocyanins (Chapter 6). Academic Press, 2009: 508p.

[297] Mensinga TT et al. ; Potato glycoalkaloids and adverse effects in humans: an ascending dose study. Regul Toxicol Pharmacol, 2/2005, 41(1): 66-72.

[298] Korpan YI et al. ; Potato glycoalkaloids: true safety or false sense of security? Trends in Biotechnology, 2004, 22(3): 147-151.

[299] Anonymous ; Waste: A source of bioactive compounds, Biotechnology Journal, 2008, 3(7): 1.

[300] Anonymous; La santé vient en mangeant: le guide alimentaire pour tous. Programme national nutrition-santé (PNNS): 2002: $130 \mathrm{p}$.

[301] Weaver C and Marr ET; White Vegetables: A Forgotten Source of Nutrients: Purdue Roundtable Executive Summary. Advances in Nutrition, 2013, 4: 318S-326S. 